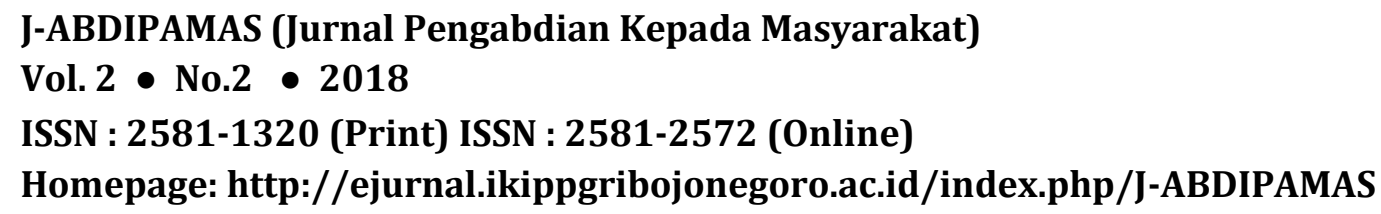

\title{
PENYULUHAN PENGINTEGRASIAN NILAI KARAKTER DALAM PEMBELAJARAN BERBASIS KURIKULUM 2013 DI SEKOLAH
}

\author{
Yoga Budi Bhakti ${ }^{1}$, Irnin Agustina Dwi Astuti2 ${ }^{2}$, Harun Rasjid ${ }^{3}$, Sumiah Nasution ${ }^{4}$ \\ ${ }^{1}$ Universitas Indraprasta PGRI. Email: bhaktiyoga.budi@gmail.com \\ 2 Universitas Indraprasta PGRI. Email: irnin.agustina@gmail.com \\ 3 Universitas Indraprasta PGRI. Email: harun.rasjid@gmail.com \\ 4 Universitas Indraprasta PGRI. Email: sumiah.nasution@gmail.com
}

\begin{abstract}
The purpose of community service activities is to provide counseling about the value of character in the learning curriculum 2013 as well as provide training to measure the student's attitudes in learning process. The value of character is considered necessary and make it a requirement in the increase or graduation in learning in the curriculum 2013. This service is done in three stages, there are planning, implementation, and evaluation. The planning stage is to prepare the presentation materials of character value integration in learning and values and attitudes measurement, training and extension module, and facilities and infrastructure in supporting the training. Implementation stage is training activities conducted on December 20-21, 2016. Evaluation stage is to provide evaluation of the training participants' products results in the implementation plan of learning and assessment of the performance of the participants. The methods used in this activity are training and mentoring and discussion. Training is done by providing information in knowing the value of the characters contained in the learning and providing training on how to measure values and attitudes. The results of this activity teachers can understand and apply the value of characters in learning in school.
\end{abstract}

Keywords : 2013 curriculum; character value; integrated.

\begin{abstract}
ABSTRAK
Tujuan kegiatan pengabdian masyarakat ini adalah untuk memberikan penyuluhan tentang nilai karakter dalam pembelajaran di kurikulum 2013 serta memberi pelatihan untuk mengukur sikap peserta didik dalam pembelajaran. Nilai karakter dipandang perlu dan menjadikannya sebagai syarat dalam kenaikan ataupun kelulusan dalam pembelajaran di kurikulum 2013. Kegiatan ini dilakukan dalam tiga tahap yaitu tahap perencanaan, pelaksanaan, dan evaluasi. Tahap perencanaan yaitu menyiapkan bahan presentasi integrasi nilai karakter dalam pembelajaran dan pengukuran nilai dan sikap, modul pelatihan dan penyuluhan, serta sarana dan prasarana dalam menunjang pelatihan. Tahap pelaksanaan yaitu kegiatan pelatihan yang dilaksanakan pada tanggal 20-21 Desember 2016. Tahap evaluasi yaitu memberikan evaluasi terhadap hasil produk peserta pelatihan dalam rencana pelaksanaan pembelajaran dan penilaian performa peserta. Metode yang digunakan dalam kegiatan pelatihan ini adalah dengan pelatihan dan pendampingan serta diskusi. Pelatihan dilakukan dengan cara memberikan informasi dalam mengetahui nilai karakter yang terkandung dalam pembelajaran dan memberikan pelatihan tentang cara mengukur nilai dan sikap. Hasil produk pelatihan ini dalam bentuk rencana pelaksanaan pembelajaran yang dapat dikembangkan lagi.
\end{abstract}

Kata Kunci : kurikulum 2013, nilai karakter, integrasi. 


\section{PENDAHULUAN}

Pendidikan adalah sebuah usaha yang ditempuh oleh manusia dalam rangka memperoleh ilmu yang kemudian dijadikan sebagai dasar untuk bersikap dan berperilaku. Karena itu, pendidikan merupakan salah satu proses pembentukan karakter manusia. Pendidikan bisa juga dikatakan sebagai proses pemanusiaan manusia. Dalam keseluruhan proses yang dilakukan manusia terjadi proses pendidikan yang akan menghasilkan sikap dan perilaku yang akhirnya menjadi watak, kepribadian, atau karakternya (Bhakti \& Astuti, 2018). Untuk meraih derajat manusia seutuhnya sangatlah tidak mungkin tanpa melalui proses pendidikan. Setiap bangsa akan maju karena pendidikannya, pendidikan maju merupakan jantung dan denyut nadi bangsa (Bhakti, 2017).

Sejalan dengan laju perkembangan masyarakat, pendidikan menjadi sangat dinamis dan disesuaikan dengan perkembangan yang ada. Kurikulum pendidikan bukan menjadi patokan yang baku dan statis, tetapi sangat dinamis dan harus menyesuaikan dengan situasi dan kondisi yang ada. Dalam rangka ini reformasi pendidikan menjadi urgen agar pendidikan tetap kondusif. Reformasi pendidikan harus terprogram dan sistemik. Reformasi terprogram menunjuk pada kurikulum atau program suatu institusi pendidikan, misalnya dengan melakukan inovasi pendidikan. Inovasi dilakukan dengan memperkenalkan ide baru, metode baru, dan sarana prasarana baru agar terjadi perubahan yang mencolok dengan tujuan dan maksud tertentu. Adapun reformasi sistemik terkait dengan hubungan kewenangan dan distribusi serta alokasi sumber daya yang mengontrol sistem pendidikan secara keseluruhan. Hal ini sering terjadi di luar sekolah dan berada pada kekuatan sosial dan politik. Reformasi sistemik menyatukan inovasi-inovasi yang dilakukan di dalam sekolah dan di luar sekolah secara luas (Zainuddin, 2008: 33-34).

Beberapa tahun terakhir pendidikan kita telah mengalami perubahan kurikulum seperti diberlakukannya Kurikulum Berbasis Kompetensi (KBK) tahun 2004 yang disusul dengan Kurikulum Tingkat Satuan Pendidikan (KTSP) tahun 2006. Di samping itu, juga telah dilakukan berbagai inovasi dalam rangka pencapaian tujuan pendidikan nasional seperti tertuang dalam Undang-Undang No. 20 tahun 2003 tentang Sistem Pendidikan Nasional (lihat bab 2 pasal 3). Salah satu bentuk inovasi ini adalah dicanangkannya pendidikan karakter bangsa melalui berbagai proses pendidikan (Kemdikbud, 2014). Dari fungsi dan tujuan yang ingin dicapai, pendidikan karakter tidak hanya merupakan inovasi pendidikan, tetapi juga merupakan reformasi pendidikan yang harus dipersiapkan dan dilaksanakan dengan benar serta melibatkan setiap pihak yang terkait dengan penyelenggaraan pendidikan. Perangkat pembelajaran pada Kurikulum 2013 yang membedakan dengan KTSP yaitu dari komponen RPP seperti adanya empat Kompetensi Inti (KI). Pembelajaran yang dirancang harus memenuhi keempat KI. Adanya KI ini diharapkan terbentuknya sumber daya manusia yang terdidik dan berkarakter (Mulyatna, dkk 2018).

Berdasarkan fungsi dan tujuan pendidikan nasional, jelas bahwa pendidikan di setiap jenjang, mulai pendidikan dasar hingga pendidikan tinggi, harus dirancang dan diselenggarakan secara sistematis guna mencapai tujuan tersebut (Kemdiknas, 2010). 
Dalam rangka pembentukan karakter peserta didik sehingga beragama, beretika, bermoral, dan sopan santun dalam berinteraksi dengan masyarakat, maka pendidikan harus dipersiapkan, dilaksanakan, dan dievaluasi dengan baik dan harus mengintegrasikan pendidikan karakter di dalamnya guna mewujudkan insan-insan Indonesia yang berkarakter mulia. keluarga merupakan lingkungan pertama bagi pertumbuhan karakter anak. Oleh karena itu sangatlah tepat jika pendidikan karakter dimulai dari lingkungan keluarga. Setelah itu, barulah pendidikan karakter dilakukan di sekolah (Sutijan, 2015:4).

Pada dasarnya pendidikan bermuara pada pembentukan karakter (character building) karena pendidikan karakter sangat penting membentuk manusia yang berkualitas. Untuk itu guru merupakan pendidik yang harus membentuk karakter anak sejak dini (Susilawati, 2016:67). Pendidikan karakter seharusnya membawa peserta didik ke pengenalan nilai secara kognitif, penghayatan nilai secara afektif, dan akhirnya ke pengamalan nilai secara nyata. Inilah rancangan pendidikan karakter (moral) yang oleh Thomas Lickona disebut moral knowing, moral feeling, dan moral action (Lickona, 1991: 51). Karena itulah, semua mata pelajaran yang dipelajari oleh peserta didik di sekolah harus bermuatan pendidikan karakter yang bisa membawanya menjadi manusia yang berkarakter.

Pendidikan karakter sendiri bertujuan untuk menanamkan nilai dalam diri siswa dan pembaruan tata kehidupan bersama yang lebih menghargai kebebasan individu (Salim, 2015:112). Pendidikan karakter juga bertujuan meningkatkan mutu penyelenggaraan dan hasil pendidikan di sekolah yang mengarah pada pencapaian pembentukan karakter dan akhlak mulia peserta didik secara utuh, terpadu dan seimbang sesuai dengan standar kompetensi lulusan (Patmawati, 2013).

Kurikulum yang dibutuhkan sekarang adalah kurikulum yang bisa memperkuat kompetensi (pengetahuan, keterampilan, dan sikap) dan bisa menumbuhkan kecintaan dan kebanggaan generasi bangsa yang bangga menjadi bangsa Indonesia. Untuk menciptakan harapan generasi tersebut perlu metodologi dan materi pembelajaran yang merangsang tumbuhnya kepenasaran intelektual dengan lebih menonjolkan melalui membangun pola pikir, tradisi, dan budaya keilmuan, menumbuhkan kreativitas dan sekaligus daya inovasi, itulah salah satu jiwa kurikulum 2013 (Mussolikhah, 2015:206).

Kurikulum baru yang telah digulirkan sejak tahun 2013 yang lalu, pada tahun pelajaran 2016/2017 ini akan diterapakan sekolah-sekolah seluruh Indonesia secara bertahap. Tahun sebelumnya, Kurikulum 2013 hanya diterapkan pada beberapa sekolah yang sudah dianggap siap saja.

Berbeda dengan Kurikulum KTSP, pada Kurikulum 2013 beberapa perangkat pembelajaran disediakan oleh pemerintah pusat, seperti silabus, buku ajar. Peserta didik tidak perlu membeli Lembar Kerja Peserta didik (LKS), karena buku peserta didik Kurikulum 2013 telah dilengkapi LKS. Kurikulum 2013 untuk jenjang SD menggunakan pendekatan pembelajaran tematik.

Tema menjadi pengikat beberapa materi mata pelajaran yang harus disampaikan guru. Dalam Kurikulum 2013 setiap kelas disediakan beberapa tema yang memiliki 
subtema, dan setiap subtema terdiri dari beberapa pembelajaran. Permasalahan yang dihadapi Guru dalam mengimplementasikan Kurikulum 2013, Diklat dan bimtek Implementasi Kurikulum 2013 bagi guru diikuti oleh sebagian kecil guru. Sementara di Lapangan harus sudah mengimplementasikannya. Salah satu permasalahan yang dihadapi guru mata pelajaran adalah kesulitan mengintegrasikan nilai karakter dalam mata pelajaran yang bersesuaian dengan kurikulum 2013. Permasalahan tersebut berawal dari latar belakang kualifikasi pendidikan Guru, yaitu dari berbagai disiplin ilmu.

Guru kesulitan menganalisis keterkaitan nilai karakter dalam SKL, KI dan KD dan membuat Indikator pencapaian kompetensi untuk dituangkan dalam rancangan pembelajaran dan melaksanakan pembelajaran disekolah. Atas dasar asumsi tersebut, maka perlu untuk dilakukan kegiatan meningkatkan kemampuan guru dalam mengintegrasikan nilai karakter dalam pembelajaran di sekolah.

\section{METODE PELAKSANAAN}

Sasaran kegiatan ini adalah guru di lingkungan Yayasan Raudhatul Jannah Ciawi. Kegiatan ini dilaksanakan pada tanggal 20-21 Desember 2016.

Program pengabdian masyarakat ini dilaksanakan dengan menggunakan metode penyuluhan (sosialisasi), pelatihan dan simulasi. Penyuluhan (sosialisasi) dilakukan dengan memberikan pengetahuan dan pemahaman mengenai cara membuat rencana pelaksanaan pembelajaran, mulai dari langkah-langkah pembuatan rancangan pelaksanan pembelajaran, dasar-dasar memilih model pembelajaran yang tepat, sampai bagaimana membuat rancangan pelaksanaan pembelajaran.

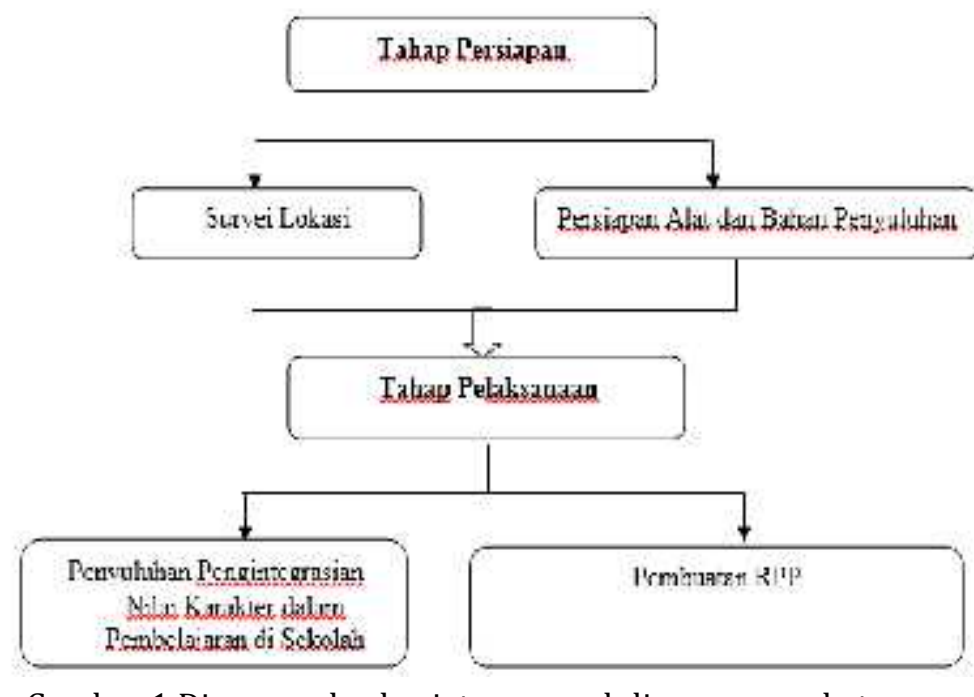

Gambar 1 Diagram alur kegiatan pengabdian masyarakat

Pelaksanaan kegiatan pengabdian masyarakat ini dilakukan dalam tiga tahap, yaitu tahap persiapan, pelaksanaan, dan praktek. Tahap pertama penyuluhan. Tahap ini adalah tahap persiapan. Pada tahap ini tim melakukan survei pendahuluan untuk mengetahui kondisi mitra di lapangan, tempat yang akan digunakan, dan menyusun rancangan kegiatan yang akan dilakukan. Tahap persiapan selanjutnya tim menyiapkan bahan-bahan dan perlengkapan yang akan digunakan dalam kegiatan ini. 
Tahap kedua, yaitu tahap pelaksanaan memberikan pengetahuan dan pemahaman mengenai cara mengintegrasikan nilai karakter dalam pembelajaran di Sekolah, mulai dari langkah-langkah pembuatan rancangan pelaksanan pembelajaran, dasar-dasar memilih model pembelajaran yang tepat, sampai bagaimana membuat rancangan pelaksanaan pembelajaran

Tahap ketiga adalah mempraktekan langsung kepada guru bagaimana membuat rancangan pelaksanaan pembelajaran. Pada tahap ini para guru diminta membuat satu buah rancangan pelaksanaan pembelajaran yang memuat dan dapat mengukur nilai karakter.

\section{HASIL DAN PEMBAHASAN}

Program pengabdian kepada masyarakat ini telah dilaksanakan pada tanggal 2021 Desember Mei 2016 di Yayasan Raudlatul Jannah Ciawi Bogor. Program pengabdian masyarakat berupa Penyuluhan Pengintegrasian Nilai Karakter Dalam Pembelajaran Berbasis Kurikulum 2013 Di Sekolah. Persoalan yang menjadi bahasan pada abdimas kali ini adalah, bagaimana menyiapkan guru-guru supaya dapat mengintegrasikan nilai karakter ke dalam pelajaran serta memberikan penyuluhan bagaimana mengukur dan menganalisis karakter dalam pelajaran.

Program ini bertujuan untuk meberikan penyuluhan tentang pengintegrasian dan mengukur nilai karakter dalam pelajaran sesuai kurikulum 2013. Harapan dari kegiatan ini adalah guru dapat mengintegrasikan nilai karakter dalam pelajaran dan juga dapat mengukur nilai sikap dalam Kegiatan Belajar Mengajar (KBM).

Pelatihan dan penyuluhan nilai karakter dalam pembelajaran banyak para guru yang belum paham tentang nilai karakter dalam pembelajaran yang dilakukan. Guru di sekolah ini masih menggunakan pembalajaran dengan tanpa melihat nilai karakter yang ada. Sarana dan prasarana yang tersedia di sekolah cukup memadai dan mendukung. Pelatihan dan penyuluhan ini dilaksanakan dua kali yaitu pada tanggal 20 dan 21 Desember 2016.

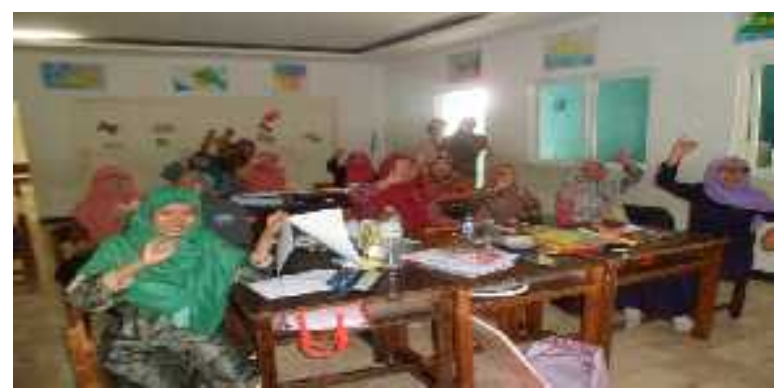

Gambar 2 Antusiasme Peserta Kegiatan Abdimas

Realisasi kegiatan ini dilakukan dalam tiga tahap, yakni tahap persiapan, pelaksanaan dan evaluasi. Tahap pertama adalah tahap persiapan. Pada tahap ini tim melakukan survei pendahuluan pada tanggal 20 Oktober 2016 untuk mengetahui kondisi ditarget kegiatan dengan menganalisis kondisi tempat yang akan digunakan, kondisi peserta yang akan diberikan perlakuan (guru) dan menyusun rancangan kegiatan yang akan dilakukan. Tahap persiapan selanjutnya tim menyiapkan bahan presentasi, materi yang akan disampaikan, sarana dan prasarana untuk melengkapi 
kegiatan pelatihan seperti laptop dan pointer laser. Pada hari pertama kegiatan, para guru diberi pengetahuan dasar mengenai kurikulum 2013 dan nilai karakter yang ada didalamnya.

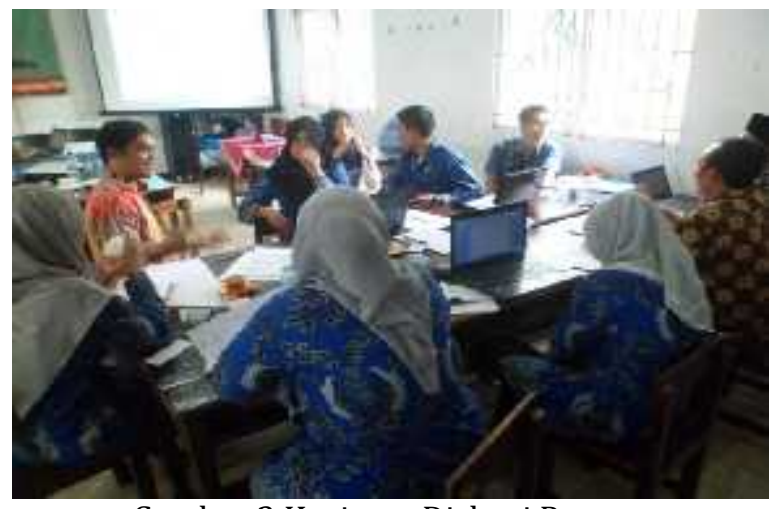

Gambar 3 Kegiatan Diskusi Peserta

Tahap selanjutnya adalah tahap pelaksanaan. Pada tahap ini tim melakukan penyuluhan materi tentang nilai karakter dalam pelajaran. Para guru diberi pengetahuan tentang bagaimana cara mengukur sikap siswa dalam pembelajaran. Peserta pelatihan adalah semua guru dan karyawan di yayasan raudlatul jannah sebanyak 40 orang. Kegiatan berlangsung diawali dengan presentasi dari tim mengenai penjelasan pendahuluan tentang nilai karakter dalam kurikulum 2013. Kemudian dilanjutkan pelatihan membuat menentukan nilai karakter yang ada dalam pelajaran melalui rencana pelaksanaan pembelajaran yang dibantu oleh tim lainnya. Selama kegiatan berlangsung guru sangat antusias mengikutinya karena kegiatan ini merupakan pertama kalinya mereka baru mendapatkan materi tentang nilai karakter yang terdapat dalam pelajaran.

Tahap terakhir adalah tahap evaluasi. Pada tahap ini, peserta pelatihan membuat sebuah rencana pelaksanaan pembelajaran dan mendemonstrasikannya, kemudian peserta lainnya menentukan nilai karakter yang terdapata dalam demonstrasi tersebut. Pada tahap evaluasi tim juga menganalisis kegiatan selama pelatihan. Secara keseluruhan tidak ada hambatan yang berarti, hanya saja pada saat pelaksanaan tidak selesai tepat waktu. Peserta pelatihan juga ada yang kurang paham mengenai menentukan nilai karakter dalam pelajaran sehingga trainer harus menjelaskan secara detail dan pelan-pelan. Solusi yang diambil dalam mengatasi hambatan di atas adalah dengan memberikan tambahan instruktur di tiap kelompok sehingga memantapkan peserta pelatihan agar lebih paham dalam penyuluhan dan pelatihan tersebut.

Keberhasilan target jumlah peserta pelatihan dapat dikatakan sangat baik. Target jumlah peserta pelatihan sebanyak 40 orang dan dalam pelaksanaan pengabdian dapat hadir sebanyak 40 orang (100\%). Hal ini didukung kepala sekolah dan guru-guru mulai dari persiapan, penyediaan tempat dan peralatannya. 


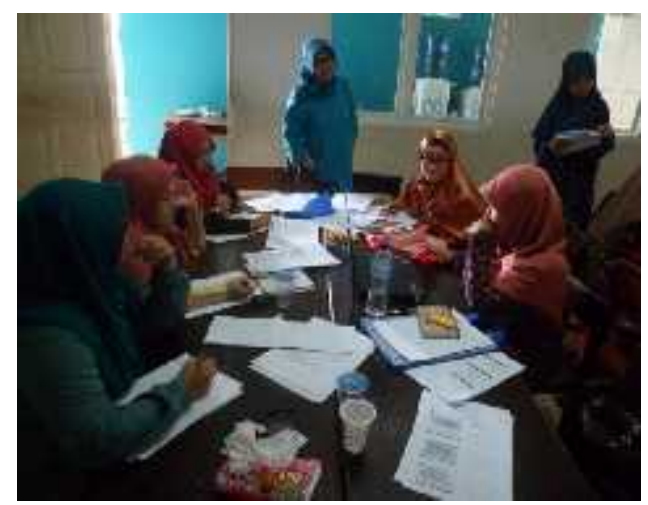

Gambar 4 Pedampingan Kelompok Oleh Tutor

Ketercapaian tujuan pelatihan dapat dikatakan baik (80\%). Kegiatan pengabdian masyarakat ini berhasil memberdayakan guru-guru di Yayasan Raudhatul jannah dengan membuat Rencana Pelaksanaan Pembelajaran sesuai dengan kurikulum 2013 yang terdapat nilai karakter didalamnya.

Ketercapaian target materi yang telah direncanakan dapat dikatakan baik (80\%). Semua materi pelatihan dapat disampaikan secara keseluruhan meskipun tidak secara detail karena keterbatasan waktu. Materi pelatihan yang telah disampaikan adalah penyuluhan pengintegrasian dan mengukur nilai karakter yang ada dalam kurikulum 2013.

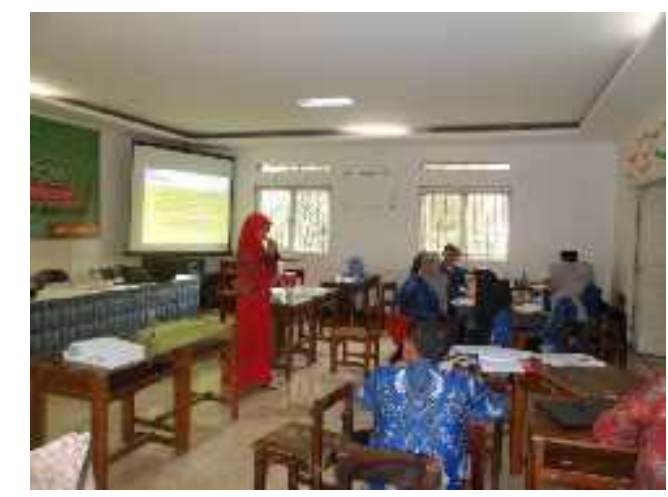

Gambar 5. Presentasi Salah Satu Peserta

Kemampuan peserta dalam penguasaan materi dapat dikatakan baik (80\%). Hal ini didukung penggunaan metode untuk meningkatkan kemampuan peserta pelatihan dalam menyerap materi yang disampaikan oleh nara sumber. Secara keseluruhan kegiatan pelatihan berhasil. Keberhasilan ini selain diukur dari keempat komponen di atas, juga dapat dilihat dari kepuasan peserta setelah mengikuti kegiatan pelatihan. Manfaat yang dapat diperoleh para peserta pelatihan adalah memahami tentang pengintegrasian nilai karakter dalam kurikulum 2013.

\section{SIMPULAN}

Secara keseluruhan kegiatan pengabdian mayarakat yang dilakukan di Yayasan raudlatul Jannah berjalan dengan baik. Guru-guru antusias mengikuti acara demi acara yang diberikan oleh tim. Dengan kegiatan pelatihan dan penyuluhan seperti ini ternyata guru memiliki minat yang tinggi, karena program seperti ini merupakan hal yang baru pertama dilakukan. Produk yang dihasilkan guru dalam bentuk rencana pelaksanaan pembelajaran yang melingkupi nilai karakter. Luaran dari kegiatan pengabdian 
masyarakat ini dalam bentuk modul pengintegrasian nilai karakter dalam kurikulum 2013 dapat digunakan oleh pengajar baik guru, dosen, maupun masyarakat umum.

\section{UCAPAN TERIMA KASIH}

Penulis mengucapkan terima kasih kepada Rektor Universitas Indraprasta PGRI, Kepala LPPM Universitas Indraprasta PGRI, Direktur LPIT Raudlatul Jannah dan Kepada Guru di LPIT Raudlatul Jannah

\section{DAFTAR RUJUKAN}

Bhakti, Y. (2017). Evaluasi Program Model CIPP pada Proses Pembelajaran IPA. JIPFRI (Jurnal Inovasi Pendidikan Fisika Dan Riset Ilmiah), 1(2), $75 \quad$ - 82. https://doi.org/10.30599/jipfri.v1i2.109

Bhakti, Y. B., \& Astuti, I. A. D. (2018). The Influence Process of Science Skill and Motivation Learning with Creativity Learn. Journal of Education and Learning, 12(1), $30-35$.

Kemendikbud, R. I. (2014). Bahan Pelatihan Kurikulum 2013.

Nasional, K. P. (2010). Desain induk pendidikan karakter. JakartaKemendiknas RI.

Lickona, T. (1991). Educating for Character. How Our Schools Can Teach Respect and Responsibility.

Mulyatna, F., Indrawati, F., \& Hartati, L. (2018). Pelatihan Pembuatan Rencana Pelaksanaan Pembelajaran (RPP) Berdasarkan Kurikulum 2013. Abdimas Dewantara, 1(1), 11-22.

Mussolikhah, D. T., \& Suputra, I. N. (2015). Implementasi Kurikulum 2013 Pada Program Keahlian Administrasi Perkantoran (APK) SMK Negeri 1 Turen Kabupaten Malang. Jurnal Pendidikan Bisnis dan Manajemen, 1(3), 206-213.

Patmawati, S. Integrasi Nilai-Nilai Pendidikan Karakter Dalam Mata Pelajaran Tata Hidang Siswa SMK Negeri 4 Yogyakarta.

Salim, A. (2016). Integrasi Nilai-Nilai Karakter Pada Pembelajaran Pendidikan Agama Islam (PAI) Studi di Madrasah Tsanawiyah (MTs) Swasta Kabupaten Kulon Progo Yogyakarta. LITERASI (Jurnal Ilmu Pendidikan), 6(2), 111-133.

Susilawati, R. N. U., \& Dewi, H. C.. (2016). Integrasi Pendidikan Karakter Dalam Pembelajaran Bahasa Inggris Pada Anak Usia Dini. Faktor Jurnal Ilmiah Kependidikan, Vol.3 No.1, Maret 2016.

Sutijan, S., Makhfud, H., Lestari, L., \& Chumdari, C. (2015). Pengembangan Instrumen Penilaian Pendidikan Karakter Terpadu. Paedagogia, 18(2), 1-9.

Zainuddin, M. (2008). Reformasi pendidikan: Kritik kurikulum dan manajemen berbasis sekolah. Pustaka Pelajar. 